\title{
Concept of reducing harmful emissions by road transport vehicles in the tourist route Karpacz- Jelenia Góra
}

\author{
Pawel Zajac ${ }^{1, *}$, Szymon Haladyn ${ }^{2}$, and Stanislaw Kwasniowski ${ }^{1}$ \\ ${ }^{1}$ Wrocław University of Technology, Faculty of Mechanical Engineering, Wybrzeże Wyspiańskiego \\ 27, 50-370 Wroclaw, Poland \\ ${ }^{2}$ Wrocław University of Technology, "Logistics" Students' Scientific Circle functioning at the Faculty \\ of Mechanical Engineering, Wybrzeże Wyspiańskiego 27, 50-370 Wrocław, Poland
}

\begin{abstract}
The research carried out by the "Logistics" Students' Scientific Circle functioning at the Faculty of Mechanical Engineering of the Wrocław University of Technology shows that every day, between the communes which cross railway lines 308 and 340, 1911 persons move in circular migrations solely due to occupational activity. Some of them could travel by rail. Eliminating 500 cars a day (i.e. 250 outwards and return travels on the route Kowary/Karpacz-Jelenia Góra) would reduce annual carbon dioxide emissions by approximately 460 tonnes. Further reductions in $\mathrm{CO}_{2}$ emissions in transport can be achieved thanks to the use of railways by tourists, of which - in the area of the communes of Karpacz, Kowary and Mysłakowice, i.e. an area of outstanding recreational valors - there was over 300,000 in 2016 [3]. Rational train running interval was determined and a timetable proposed, taking into account routes leading beyond Jelenia Góra. The paper justifies the need for the introduction of complementary communication provided by electrobuses. The concept of reactivating traffic in this area should be complemented by the construction of a Park\&Ride car park. The possibility of further development of the transport system in the area in question was also proposed.
\end{abstract}

\section{Introduction}

Hydrocarbons are oxidised in the engine of the vehicle. The main products of the reaction are: carbon dioxide (approx. 86\%) and water (approx. 13\%). The quantity of carbon dioxide (molar mass $M_{\mathrm{CO}_{2}}=44.01\left[\frac{\mathrm{g}}{\mathrm{mol}}\right]$, molar mass of carbon: $M_{C}=12\left[\frac{\mathrm{g}}{\mathrm{mol}}\right]$ ) produced per kilogram of conventional fuel is:

$$
m=\frac{44,01 \cdot 0,86}{12}=3,15[\mathrm{~kg}]
$$

Assuming an average consumption of 6 litres of conventional fuel per $100 \mathrm{~km}$ driven by a passenger car (approx. $4.3 \mathrm{~kg}$ ), the aforementioned vehicles will emit 4.2 million $\mathrm{kg}$ of

\footnotetext{
* Corresponding author: pawel.zajac@pwr.edu.pl
} 
carbon dioxide on the route in question. This indicator clearly shows the advisability of taking pro-ecological actions and supporting them by the European Union and its members in the sustainable development policy, and is also desirable in the era of electromobility. The idea of electromobility of passenger transport in this region is also supported by the situation in which Zakopane has found itself, namely: the excessive smog that contradicts the idea of tourism development and proper recreation. The Jelenia Góra Valley should do everything that is possible to avoid a similar situation.

In the area of the analyzed lines no. 308 and 340 tourist traffic develops intensively, hotel and leisure facilities are being built. Karpacz - like Zakopane - is facing inefficiency of the road system, and the peripheral location (on the border of almost three countries: PolandGermany-Czech Republic) makes it a location excluded in terms of transport. Restoring rail passenger traffic would make it possible to change this negative state and would attract Polish and German tourists to the Karpacz region, both for one-day or weekend stays and longer trips.

Karpacz's transport system is overloaded during holiday periods; cars parked on narrow streets make it difficult to move around (snow removal in winter), preventing tourists from enjoying the charm of the resort. Further development of Karpacz as a holiday resort is hindered by the shortage of parking spaces. Constructing a $\mathrm{P}+\mathrm{R}$ car park in the immediate vicinity of the railway stop on the initial section of the Jelenia Góra - Karpacz line will allow to reduce the number of cars entering the town, to reach the Jelenia Góra Valley by private means of transport, and then leave it and continue the travel by train.

Moreover, it is worthwhile to launch the new Mysłakowice Dolne stop at kilometre $7+360$. This is desirable in view of the urban development of the areas along the railway line and, consequently, the need to cover the new urbanized areas with railway transport.

Ultimately, a possibility exists of restoring rail traffic to Kowary and, in order to improve the transport coverage of the region in question, it is proposed to consider the construction of a new four-kilometre railway line from Kowary to Karpacz.

In the era of electromobility and implementation of the sustainable development policy especially in areas of high recreational and touristic value - it would be advisable to base passenger traffic on environmentally friendly means of transport. For this reason, the project of revitalisation combined with electrification of the line and construction of the Park\&Ride car park seems to be justified [1].

\section{Theoretical travel}

The basis for the development of communication solutions, especially the timetable, are traction calculations based on the train motion equation.

These calculations, so-called theoretical or minimal time travel, allow to determine the trend of changes in vehicle speed versus its traction properties and external conditions. On its basis it is possible to determine the technical travel times of individual sections, which are necessary to propose the timetable; also, energy consumption may be determined and the possibilities of its recovery in the case of electrodynamic braking estimated. This calculation is based on the train Błąd! Nie można odnaleźć źródła odwołania.

$$
m \cdot k \cdot \frac{d v}{d t}=p(v, S) \cdot Q
$$

(Bląd! W dokumencie nie ma tekstu o

$$
\text { podanym stylu.) }
$$

where: $k$ - rotational mass coefficient for a laden train being $k=1,06[-], m$ - train mass $[\mathrm{kg}](\mathrm{m}=172000 \mathrm{~kg}), Q$ - train weight $[\mathrm{kN}], p$ - unit acceleration force $[N / k N]$, comprising of the combination of the following unit forces: tractive effort $f(v)$, braking 
effort $b(v)$, train resistance effort $w(v)$ and resistance resulting from railway reductions. $i_{m}(S)$.

\subsection{Tractive effort}

Tractive effort $F$ t is the tractive force of the traction unit $31 \mathrm{WE}$. In the traction calculations the unit tractive effort Błąd! Nie można odnaleźć źródła odwołania. is used, expressing the tractive effort versus unit weight, expressed as $[k N][3]$.

$$
f=\frac{F}{Q}\left[\frac{N}{k N}\right]
$$

The calculations assume that braking effort is defined by formula (4).

$$
B=\mu_{i} \cdot m \cdot N_{i}[k N]
$$

where: $\mu_{i}$ - friction coefficient between the brake lining and the brake disc, $m$ - number of brake linings in the vehicle [-], dla $31 \mathrm{WE} m=40[-], N_{i}$ - pressure of shoe lining on the brake discs. The friction coefficient relationship $\mu_{i}$ versus speed for a disc brake [4] was adopted after Sawczuk and Jüngst. The shoe lining pressure on the brake discs is determined from the formula Błąd! Nie można odnaleźć źródła odwołania..

$$
N_{i}=N_{n o m} \cdot \xi_{i}[k N]
$$

where: $N_{\text {nom }}$ - nominal pressure on the lining, $N_{\text {nom }}=17,16[k N], \xi_{i}$ - pressure drop coefficient at a given braking degree.

The pressure drop coefficient at a given braking degree is calculated from formula Bląd! Nie można odnaleźć źródła odwołania..

$$
\xi_{i}=\frac{\Delta \mathrm{p}_{i}}{\Delta \mathrm{p}_{\text {maks }}}
$$

where: $\Delta \mathrm{p}_{\text {maks }}$ - pressure drop in the service line during emergency braking, $\Delta \mathrm{p}_{\text {maks }}=0.5[\mathrm{MPa}], \Delta \mathrm{p}_{i}$ - pressure drop in the service line for individual braking degrees; in the case of the theoretical travel performed, full (2nd degree) braking was applied $\Delta p_{2}=0.22[\mathrm{MPa}]$.

In order to be able to take into account the braking weight, the concept of unit braking effort defined by formula Błąd! Nie można odnaleźć źródła odwołania. is introduced.

$$
b=\frac{B \cdot \delta}{Q}[N / k N]
$$

where: $\delta$ - percentage of braking weight $[-], Q-$ train weight $[k N]$. The braking weight percentage value is determined using the formula Błąd! Nie można odnaleźć źródła odwolania..

$$
\delta=\frac{\varepsilon}{Q}[-]
$$

where: $\varepsilon$ - braking weight $[k N]$ expressed as: $\varepsilon=m_{h} \cdot Q$, the braking mass of $31 \mathrm{WE}$ multiple unit is $m_{h}=281[t]$. 


\subsection{Basic resistance effort}

Calculations of the multiple unit resistance effort were based on the guidelines developed at the Railway Institute in Warsaw (formerly CNTK) given in [5].

$$
W=0,67 \cdot v^{2}+25,8 \cdot v+2618[k N]
$$

\subsection{Additional resistance effort (from profile)}

In order to carry out the calculations, the profile of the analyzed railway line was reduced by reducing the elevation and gradients, as well as curves of tracks. The so-called profile resistance [6] is then determined. For reduction of resistance effort on curves, the relation Błąd! Nie można odnaleźć źródła odwołania. was assumed [3].

$$
i_{\mathrm{f}}=\frac{\sum l_{\mathrm{l}} \cdot \frac{690}{r_{\mathrm{t}}}}{\Delta l}[\% \mathrm{\%}] \operatorname{lub}\left[\frac{N}{k N}\right]
$$

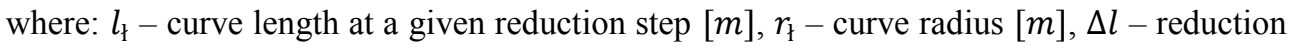
step value $[m]$. The reduction of a railway line consists in summing the values of all local resistance components occurring at a given reduction step Błąd! Nie można odnaleźć źródła odwolania.. Fig. 4 shows the profile characteristics of the analyzed line.

$$
i_{m}=i_{w}+i_{\mathrm{f}}[\%]
$$

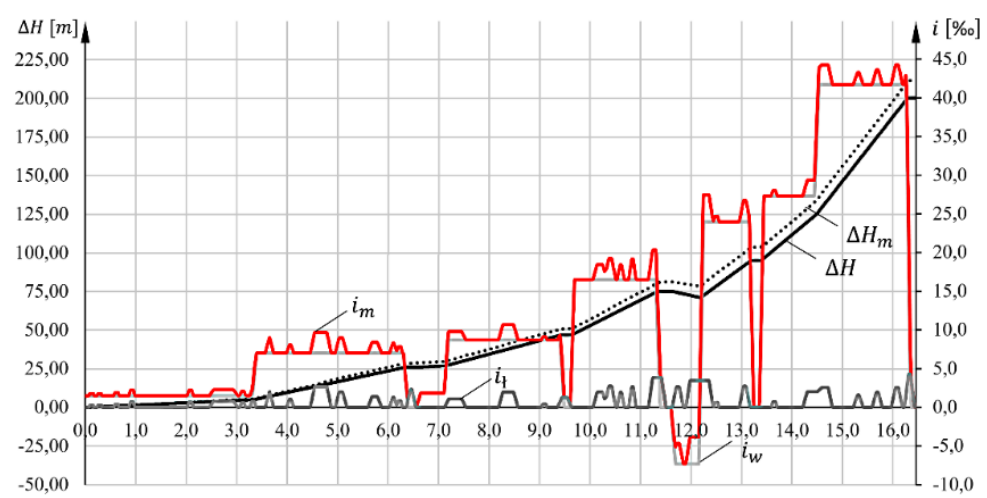

Fig. 1. Reduction of railway line Jelenia Góra-Karpacz.

\subsection{Calculation of theoretical travel}

The calculations assume that the train moves at maximum speed $v=60[\mathrm{~km} / \mathrm{h}]$. A fragment of the calculation results is shown in Fig. 5. Calculations were carried out for the whole route Jelenia Góra-Karpacz, outwards and return. The calculations showed that the time needed for the multiple unit to complete the route to Karpacz (without stoppages, but taking into account stops and acceleration) is $18.77[\mathrm{~min}]$, return travel: $18.80[\mathrm{~min}]$. 

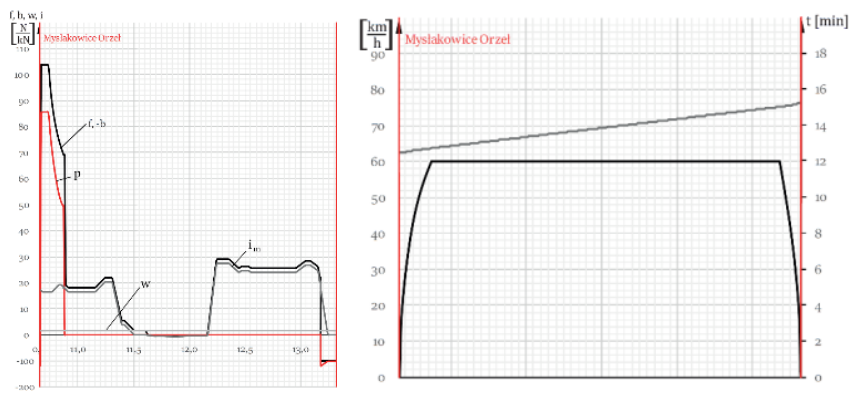

Fig. 2. Portion of theoretical ride $31 \mathrm{WE}$ emu from Jelenia Góra to Łomnica Średnia.

\section{Proposed transport offer}

\subsection{Scheduled travel time}

The realization of theoretical travel leads to the determination of the technical travel time of the train, which determines the timetable to the greatest extent. It is - according to the Instruction [7] - a component A of the train's travel time. The operating reserve is component $\mathrm{B}$ (for a passenger train it is $5[\mathrm{~min}]$ for each $100[\mathrm{~km}]$ of travel). Component $\mathrm{D}$ is the sum of stopping times at stops and intermediate stations, but the minimum commercial standstill time for an electric multiple unit is $0^{3}[\mathrm{~min}]$. The total scheduled train travel time between Jelenia Góra - Karpacz and Karpacz - Jelenia Góra is presented in Table 1.

Table 1. Transfer time for route Jelenia Góra-Karpacz.

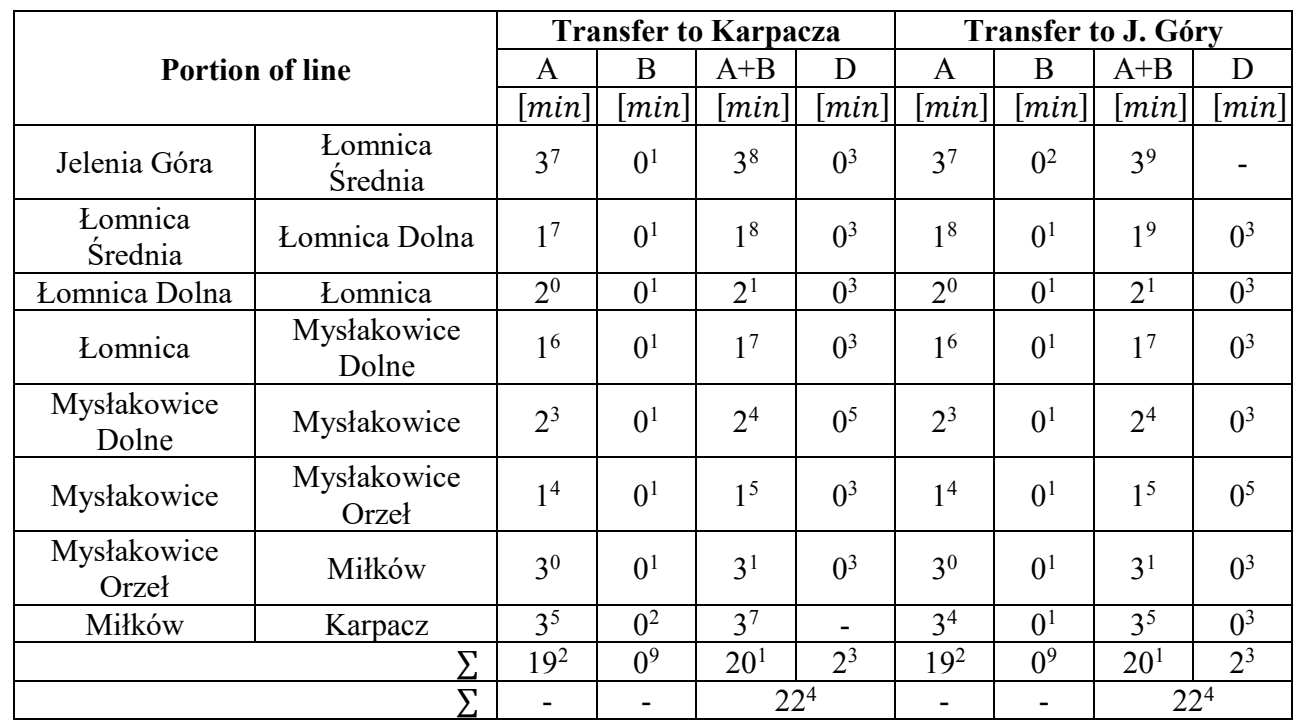

Source:own elaboration

The analysis showed that the scheduled, minimum time of train travel between Jelenia Góra and Karpacz is $t_{T}=22.4[\mathrm{~min}]$ and is consistent with the time needed to complete the return ride.

\subsection{Route capacity}


The minimum time required to complete the outward and return journey is equal to the value given by the formula Błąd! Nie można odnaleźć źródła odwołania..

$$
t_{m}=\sum t_{j_{i}}+\sum t_{j_{j}}+\sum_{k=1}^{n} t_{p_{1 k}}+\sum_{k=1}^{n} t_{p_{2 k}}+\sum_{l=1}^{n} t_{z_{l}}+t_{r}[\mathrm{~min}]
$$

where: $n$ - number of intermediate commercial travel time between stopovers on the way outwards $[\mathrm{min}], t_{j_{j}}$ - travel time between stopovers on the return way $[\mathrm{min}], t_{p_{1 k}}-$ stopover time between stops on the way outwards $[\mathrm{min}], t_{p_{2 k}}-$ stopover time between stops on the return way $[\mathrm{min}], t_{z}$ - locomotive changeover time $[\mathrm{min}], t_{r}$ - time reserve confirming to the guidelines contained in [7] [ $\mathrm{min}]$.

In the considered case of transport route from Jelenia Góra to Karpacz, the minimum time needed for the outwards and return travel, after filling the determined data into formula Bląd! Nie można odnaleźć źródła odwołania. and taking into account the six-minute time needed to complete the locomotive changeover is $t_{m}=56.8[\mathrm{~min}]$. This means that it is possible to run trains cyclically in sixty minutes.

In the event of traffic revival on the analyzed route, a half-hour cycle could be introduced this solution would require recreation of the passing siding on the route in Mysłakowice, which would enable the passing of trains on the single-track line.

\subsection{Timetable assumptions}

The basic route is assumed to be a Jelenia Góra-Karpacz-Jelenia Góra shuttle. Moreover, during periods of increased tourist traffic (winter/summer holidays, public holidays, long weekends) it is planned to launch trains on a route running beyond Karpacz - namely to Wrocław. At a later stage, consideration should be given to launching connections also to Węgliniec.

It is reasonable for trains to run from around 5.00 am to around $10.30 \mathrm{pm}$. These times being turning points in a way - are determined by the working hours of business. An important factor is also the need to ensure connections with Jelenia Góra for young students.

From the point of view of tourist traffic, it is particularly desirable to provide a possibility of reaching the place of rest in the late morning (about 10:00 a.m.) and returning from it at about 6:00 p.m. Establishing the above time frames would allow the residents of Wrockaw situated about $140[\mathrm{~km}]$ apart for comfortable arranging of one-day and weekend trips.

\subsection{Proposed timetable}

It is proposed to start a total of 18 pairs of shuttle trains on the route of Jelenia Góra-Karpacz -Jelenia Góra per working day, which translates into train operation of $592.56[\mathrm{wz} \mathrm{km}]$. It is planned to implement travels at hourly rate; the first connection would be made from Jelenia Góra station before 5.00 a.m., while the last arrival at the destination station is expected after 11.00 p.m.

For public holidays it is assumed that 12 pairs of trains on the route Jelenia Góra-Karpacz -Jelenia Góra and one pair of connections on the route Wrocław Główny-Karpacz-Wrocław Główny will be launched. Train operation will be reduced compared to working day to a level of $427.96[\mathrm{wzkm}]$.

The projected timetable is presented in the form of Table 246 of the Network Train Schedule (Table 2).

\section{Buffer parking arrangement}


The road system of the eastern resorts of the Giant Mountains suffers - especially during the tourist season - from significant overload. Difficulties are caused particularly by parked cars. As a result, it is justified to construct a Park\&Ride car park located in the immediate vicinity of one of the initial access points to the Carpathian line. It is proposed to provide parking spaces for 500 vehicles in the first stage. According to the standard proposed by Wł. Czarnecki in [8], such a car park would occupy an area of about 1.2 ha depending on the layout of parking spaces and internal roads used. The analysis of the spatial development status showed that an adequate area is located in the immediate vicinity of the Lomnica Średnia passenger stop.

Historical and terrain conditions have determined the course of railway lines 308 and 340, making it impossible for the railway to reach all areas which are significant population centres, so that sometimes a passenger stop or station is located at a disadvantageous distance from traffic generators, and the access route - from the point of view of potential railway customers - is excessively long.

In order to increase the accessibility of the railway connection between Jelenia Góra and Karpacz, in the two cases described above it is proposed to launch a complementary bus service (connected with the trains) on the routes: Karpacz (railway station)-Bierutowice- the outwards and return travel time is 32 minutes, and Mysłakowice (railway station)Kostrzyca-Kowary - the outwards and return travel time is 26 minutes; hence it is possible to extend some of the routes towards the power tunnel.

Table 2. Projected timetable.

\section{JELENIA GORA - MYSŁAKOWICE - KARPACZ}

\begin{tabular}{|c|c|c|c|c|c|c|c|c|c|c|c|c|c|c|c|c|c|c|c|c|}
\hline $\begin{array}{l}\text { Wroclaw Glówny } \\
\text { Jelenia Góra }\end{array}$ & & & & & & & & $\begin{array}{r}x \\
x \\
\end{array}$ & & & & & & & & & & & & \\
\hline $\begin{array}{l}\text { termin kursowat } \\
\text { przewoźnik - katego }\end{array}$ & & $\begin{array}{c}\text { (1) } \\
\mathrm{KD}-\mathrm{OS}\end{array}$ & $\mid \begin{array}{c}0 \\
K D-O S\end{array}$ & $K D-O s$ & $\begin{array}{c}0 \\
K D-O S\end{array}$ & $K D-O s$ & $\begin{array}{c}0 \\
K D-O S\end{array}$ & $\left|\begin{array}{c}0 \\
K D-O S\end{array}\right|$ & $K D-O s$ & KD $-O s$ & KD - Os & $K D-O s$ & $K D-O s$ & KD $-O s$ & KD $-O s$ & KD - Os & $S$ KD - Os & SD-OS & isD - Os & $\begin{array}{c}0 \\
K D-O s\end{array}$ \\
\hline informa cje dodatko & & $=60 \%$ & abios & $=\cos$ & abot & $\Rightarrow$ ict & ando & abios & $=306$ & asios & abio & abob & 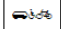 & ais & 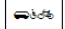 & $=\operatorname{sob}$ & abos & abiot & $=-10 \%$ & ais \\
\hline & & $60500 / 1$ & $160502 / 3$ & $360504 / 5$ & $560506 / 7$ & 60508/9 & $00510 / 1$ & $160512 / 3$ & $360514 / 5$ & $60516 / \pi$ & $60518 / 9$ & $60520 / 1$ & $60522 / 3$ & $60524 / 5$ & $560526 / 7$ & $60528 / 9$ & $960530 / 1$ & $160532 / 3$ & /360534/5 & $560536 / 7$ \\
\hline JELENIA GÓRA & 0. & \$04:42 & $\$ 05: 42$ & $06: 42$ & $2 \leqslant 07: 42$ & $08: 42$ & \$09:42 & $\xi 09: 42$ & $10: 42$ & $11: 42$ & $12: 42$ & $13: 42$ & $14: 42$ & $15: 42$ & $16: 42$ & $17: 42$ & \begin{tabular}{l|l}
2 & $18: 42$ \\
\end{tabular} & $2 \leqslant 19: 42$ & \begin{tabular}{l|l|}
2 & $20: 42$ \\
\end{tabular} & $\$ 22: 17$ \\
\hline mnica Średnia & । & §04:46 & $\xi 05: 46$ & $06: 46$ & $607: 46$ & $08: 46$ & \$09:46 & $\xi 09: 46$ & $10: 46$ & $11: 46$ & $12: 46$ & $13: 46$ & $14: 46$ & $15: 46$ & | $16: 46$ & $17: 46$ & \begin{tabular}{l|l}
6 & $18: 46$
\end{tabular} & $6 \xi 19: 46$ & $20: 46$ & $\xi 22: 21$ \\
\hline omnica Dolna & & $\xi 04: 48$ & \$ $05: 48$ & $06: 48$ & 3 \$ 07:48 & 08:48 & $\leqslant 09: 48$ & $\xi 09: 48$ & \begin{tabular}{l|l|} 
& $10: 48$ \\
\end{tabular} & $11: 48$ & $12: 48$ & $13: 48$ & $14: 48$ & $15: 48$ & \begin{tabular}{l|l|} 
& $16: 48$ \\
\end{tabular} & $17: 48$ & \begin{tabular}{l|l}
8 & $18: 48$ \\
\end{tabular} & $8 \xi 1$ & $20: 48$ & $\xi 22: 23$ \\
\hline mnica & 1 & $\xi 04: 50$ & $\$ 05: 50$ & $06: 50$ & 0 07:50 & 08:50 & $\$ 09: 50$ & $\$ 09: 50$ & $0: 50$ & 1:50 & $12: 50$ & 13:50 & $14: 50$ & 5:50 & \begin{tabular}{|l|}
$16: 50$ \\
\end{tabular} & $17: 50$ & \begin{tabular}{l|l}
0 & $18: 50$
\end{tabular} & | $19: 50$ & \begin{tabular}{l|l|}
0 & $20: 50$ \\
\end{tabular} & $\xi 22: 25$ \\
\hline Myslakowice Dolne & $t$ & \$ 04:52 & $\S 05: 52$ & $06: 52$ & $\{07: 52$ & 08:52 & $\leqslant 09: 52$ & \$09:52 & $0: 52$ & $11: 52$ & $12: 52$ & 3:52 & 4:52 & 5:52 & $16: 52$ & $17: 52$ & \begin{tabular}{l|l}
2 & $18: 52$ \\
\end{tabular} & $2 \leqslant 19: 52$ & $20: 52$ & $\xi 22: 27$ \\
\hline \multirow{2}{*}{ Mysłakowice } & p. & \$ $04: 55$ & \$ $05: 55$ & $06: 55$ & $5 \xi 07: 55$ & $08: 55$ & $\xi 09: 55$ & ₹ $09: 55$ & $10: 55$ & 55 & $12: 55$ & 3:55 & $4: 55$ & 55 & 55 & $17: 55$ & $18: 55$ & $5 \leqslant 19: 55$ & 55 & $\$ 22: 30$ \\
\hline & 0. & ई $04: 55$ & \$ $05: 55$ & $06: 55$ & $5 \xi 07: 55$ & $08: 55$ & ई $09: 55$ & ई $09: 55$ & $10: 55$ & 55 & $: 55$ & 5 & 5 & $5: 55$ & $6: 55$ & 1 & $8: 55$ & $5 \xi 1$ & 51 & \\
\hline lystakowice Orzel & 1 & $\xi 04: 57$ & \$05:57 & $06: 57$ & $7\{07: 57$ & 08:57 & \$09:57 & \$ 09:57 & $: 57$ & $: 57$ & $12: 57$ & $: 57$ & $1: 57$ & $5: 57$ & $6: 57$ & $17: 57$ & 8:57 & $7 \mid \xi 1$ & 57 & $\xi 22: 32$ \\
\hline litków & $t$ & $\xi 05: 00$ & $\xi 06: 00$ & $07: 00$ & $0 \leqslant 08: 00$ & 09:00 & $\leqslant 10: 00$ & $\leqslant 10: 00$ & $1: 00$ & 100 & 13:00 & 00 & $15: 00$ & $16: 00$ & $17: 00$ & $18: 00$ & \begin{tabular}{l|l}
0 & $19: 00$
\end{tabular} & $0 \leqslant 20: 00$ & \begin{tabular}{l|l|}
0 & $21: 00$ \\
\end{tabular} & $\xi 22: 35$ \\
\hline arpacz & p. & $\xi 05: 04$ & $+\xi 06: 04$ & 07:04 & $4\left\{\begin{array}{l}4: 04 \\
\end{array}\right.$ & 09:04 & $\xi 10: 04$ & $\leqslant 10: 04$ & $\begin{array}{l}+11: 04 \\
\end{array}$ & 12:04 & 13:04 & 14:04 & \begin{tabular}{|l}
$15: 04$ \\
\end{tabular} & $\begin{array}{l}+\mid 16: 04 \\
\end{array}$ & $\begin{array}{l}4 \mid 17: 04 \\
\end{array}$ & 18:04 & 19:04 & $4 \mid \xi 20: 04$ & $21: 04$ & $\$ 22$ \\
\hline \multirow{4}{*}{\multicolumn{2}{|c|}{$\begin{array}{l}\text { termin kursowania } \\
\text { przewożnik- kategoria } \\
\text { informacje dodatkowe } \\
\text { numer pociagu }\end{array}$}} & & & & & & & & & & & & & & & & & & & \\
\hline & & KD-Os & KD- Os & $K D-O s$ & KD-Os & KD - Os & $K D-O s$ & KD - Os & KD - Os & KD - Os & KD - Os & $K D-O s$ & KD - Os & $\mathrm{KD}-\mathrm{Os}$ & KD-Os & KD - Os & $\mathrm{s}$ KD - Os & $S K D-O s$ & S $K D-O s$ & $K D-O s$ \\
\hline & & Disक & 二ंडक & काiक & $\Rightarrow 30 \%$ & काis & $\Rightarrow$ काष & 口ich & 二isot & ais & 二ंबक & 口isक & 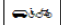 & कांक & ais & कांक & $\Rightarrow \mathrm{s} 0 \mathrm{\omega}$ & $\Rightarrow$ aich & ais & $=\operatorname{cic}$ \\
\hline & & $60600 / 1$ & $160602 / 3$ & $60604 / 5$ & $\$ 60606 / 7$ & $760608 / 9$ & $90610 / 1$ & $160612 / 3$ & $360614 / 5$ & $60616 / \pi$ & $60618 / 9$ & 60620/1 & $60622 / 3$ & $360624 / 5$ & $560626 / 7$ & $60628 / 9$ & $960630 / 1$ & $160632 / 3$ & $360634 / 5$ & $560636 / 7$ \\
\hline Karpacz & 0. & ₹ $05: 11$ & \$06:11 & 07:11 & $1 \xi 08: 11$ & 09:11 & $10: 11$ & $11: 11$ & $12: 11$ & 13:11 & 14:11 & 15:11 & 16:11 & $17: 11$ & ₹18:11 & $\xi 18: 11$ & \begin{tabular}{l|l|}
$19: 11$ \\
\end{tabular} & $1 \xi 20: 11$ & $1 \mid 21: 11$ & $\xi 22: 46$ \\
\hline ilkón & I & $\xi 05: 14$ & $4 \xi 06$ & & $4 \xi 08$ & & & & & & & & & & & & 14 & & $: 14$ & \\
\hline Mys & $\downarrow$ & $\xi 05$ & 3 06 & 18 & $8 \xi 08$ & 18 & 18 & :18 & 18 & 8 & 8 & 8 & 8 & 18 & ई & \$1 & :18 & $8 \xi 2$ & 18 & $\leqslant 2$ \\
\hline \multirow{2}{*}{ Mysłakowic } & p. & $\xi 05: 20$ & $\$ 06: 20$ & $07: 20$ & $\$ 0820$ & $09: 20$ & $10: 20$ & $11: 20$ & 12.20 & $13: 20$ & $14: 20$ & $15: 20$ & $16: 20$ & \begin{tabular}{|l|}
1720 \\
\end{tabular} & $\xi 1820$ & $\xi 18: 20$ & $19: 20$ & $0 \leqslant 20: 20$ & 2120 & $\$ 22: 55$ \\
\hline & 0. & $\xi 05: 20$ & $\$ 06: 20$ & $07: 20$ & $\$ 08: 20$ & $09: 20$ & $10: 20$ & $11: 20$ & 12.20 & $13: 20$ & $14: 20$ & $15: 20$ & $16: 20$ & $17: 20$ & $\xi 18: 20$ & $\xi 18: 20$ & \begin{tabular}{l|l}
0 & $19: 20$ \\
\end{tabular} & $0 \leqslant 20: 20$ & 120 & $\$ 22: 55$ \\
\hline vice Dolne & 1 & $\xi 05: 23$ & $\xi 06: 23$ & 07:23 & $3 \xi 08$ & 0 & $10: 23$ & $11: 23$ & - & 23 & 3 & 3 & 3 & 23 & & $\xi 1$ & 23 & $3 \xi 2$ & 23 & \\
\hline m & & $\xi 05: 25$ & $\xi 06: 25$ & 0 & $5 \xi 08$ & & & 25 & & & & 3 & 5 & 25 & & & 25 & $5 \xi 20: 25$ & 1.25 & ई 2 \\
\hline tomnica Dolna & & $\xi 05: 27$ & $\$ 06: 27$ & $07: 27$ & 7 708:27 & $09: 27$ & $10: 27$ & $11: 27$ & $7 \mid 12: 27$ & $13: 27$ & $14: 27$ & $15: 27$ & $16: 27$ & $7|17: 27|$ & \$ $18: 27$ & \$18:27 & \begin{tabular}{l|l}
7 & $19: 27$
\end{tabular} & $7 \mid \$ 20.27$ & $7 \quad 21.27$ & $\xi 23: 02$ \\
\hline & $\checkmark$ & $\xi 05: 29$ & $\{06: 29$ & $07: 29$ & $9 \leqslant 08: 29$ & $09: 29$ & $10: 29$ & $11: 29$ & $\begin{array}{l}12.29 \\
\end{array}$ & $13: 29$ & $14: 29$ & $15: 29$ & $16: 29$ & $17: 29$ & $\xi 18: 29$ & $\xi 18: 29$ & \begin{tabular}{l|l}
9 & $19: 29$
\end{tabular} & $9\} 20: 29$ & $21: 29$ & $\xi 23: 04$ \\
\hline . & p. & $\{05: 33$ & $\xi 06: 33$ & $07: 33$ & $3 \leqslant 08: 33$ & 9.35 & $0: 33$ & $1: 33$ & $2: 33$ & 3.33 & $\begin{array}{l}4.33 \\
\end{array}$ & 0.33 & 6.33 & $17: 33$ & $\xi 18: 33$ & ₹ $18: 33$ & \begin{tabular}{l|l}
3 & $19: 33$ \\
\end{tabular} & $3 \leqslant 20: 33$ & $\begin{array}{l}3 \\
\end{array}$ & $\$ 23: 0$ \\
\hline $\begin{array}{l}\text { elenia Góra } \\
\text { Vroclaw Gówny }\end{array}$ & & & & & & & & & & & & & & & & & & & & \\
\hline
\end{tabular}

\section{Resumption of traffic on the Mysłakowice-Kowary route and construction of the Kowary-Karpacz line}

The launch of a similar number of train pairs running between Jelenia Góra and Kowary, parallel to the Jelenia Góra-Karpacz connections, could generate an oversupply of connections between Jelenia Góra and Mysłakowice. On the other hand, changing trains at the station in Mysłakowice does not allow for rational use of the rolling stock and would be unattractive for travellers. Consideration should therefore be given to the possibility - much 
like the existing bus network - of running a train route to Karpacz so that it also passes through Kowary. This would require the construction of less than four-kilometre section of a single track, connecting the Kowary arch with the railway line no. 340 between Miłków and Karpacz.

Variants 1, 2, 3A and 3B implement the connection between Karpacz and Kowary in the conventional way, i.e. assuming the maintenance of the terminus in Karpacz (which is not a problem, as the rolling stock designed to operate this connection is of two-way type). They differ in the way of passing through the town of Ściegny and in the place of inclusion of the proposed line into railway line no. 340, the differences being determined by landscape and occurrence of population centres.

A different approach was taken for the preparation of variant 4. A loop arrangement covering Mysłakowice-Kowary-Karpacz-Mysłakowice was conceived. However, such a solution requires a departure from the concept of renewing traffic to the existing railway station.

\section{Summary}

The time of travel on the route being the subject of this paper, both on the route to Karpacz as well as to Jelenia Góra, will be $22^{4}[\mathrm{~min}]$. This makes it possible to run trains with a 60 minute cycle.

The proposed timetable assumes starting 18 pairs of shuttle trains per working day, 12 pairs of courses between Jelenia Góra-Karpacz-Jelenia Góra and one pair of connections between Wrocław-Karpacz-Wrocław, arranged in such a way that it is possible for the inhabitants of Wrocław to make even a one-day trip to Karpacz.

The complementary transport line planned to be launched, based on low-floor, modern electric buses, increases the availability of railway services, generating additional passenger streams, especially tourist streams (in relation to Bierutowice) and those related to daily commutes (circular migrations) - mainly on the route to Kowary. This communication - due to the use of electric and non-emission rolling stock - will contribute to the improvement of the natural environment in the Giant Mountains.

Restoration of railway traffic on the route Jelenia Góra-Mysłakowice-Karpacz will contribute to increasing the tourist and sightseeing attractiveness of this part of the Giant Mountains, it will have a positive impact on the activation and increase in the mobility of the local community. Revitalization combined with electrification of the railway line will increase the number of tourists visiting Karpacz.

\section{References}

1. Railway line nr 308 Jelenia Góra - Kamienna Góra - dolnyslask.org.pl [on-line] [access on April 12018 ] https://dolnyslask.org.pl/554495,Linia_kolejowa_nr_308_Jelenia_Gora_Kamienna_Gora.html

2. J. Podolski, J. Kacprzak, J. Myslek, Principles of electric traction (Communication and Communication Publishing, Warszawa, 1980)

3. A. Chwieduk, T. Dyr, Train traffic design (Printing Works of the Radom Polytechnic, Radom, 1997)

4. W. Sawczuk, M. Jüngst, Brake discs for rail vehicles (In: TTS. Rail Transport Technique 12, 2016)

5. J. Madej, The theory of rail vehicle traffic (Warsaw University of Technology Publishing House, Warszawa, 2012) 
6. J. Kwasnikowski, Elements of motion theory and rationalization of running a train (Scientific Publisher of the Institute for Sustainable Technologies - PIB, Radom, 2013)

7. PKP Polskie Linie Kolejowe S.A., Instruction on train timetables (Ir-11), Warszawa 2015

8. W. Czarnecki, Planning of cities and settlements. Volume II. (Places of work and residence, State Scientific Publisher, Warszawa, 1966)

9. Head Office of Geodesy and Cartography, Geoportal 2, access on April 3 2018, http://mapy.geoportal.gov.pl/imap

10. Central Statistical Office, Local Data Bank, access 26.09.2018, https://bdl.stat.gov.pl/BDL/start 